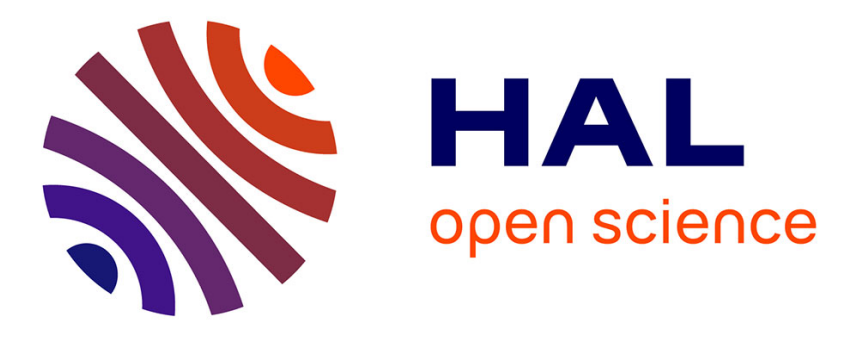

\title{
How do skilled and less-skilled spellers write text messages? A longitudinal study of sixth and seventh graders
}

Josie Bernicot, Antonine Goumi, Alain Bert-Erboul, Olga Volckaert-Legrier

\section{- To cite this version:}

Josie Bernicot, Antonine Goumi, Alain Bert-Erboul, Olga Volckaert-Legrier. How do skilled and lessskilled spellers write text messages? A longitudinal study of sixth and seventh graders. Journal of Computer Assisted Learning, 2014, 30 (6), 10.1111/jcal.12064 . hal-01392433

\section{HAL Id: hal-01392433 https://hal.science/hal-01392433}

Submitted on 4 Nov 2016

HAL is a multi-disciplinary open access archive for the deposit and dissemination of scientific research documents, whether they are published or not. The documents may come from teaching and research institutions in France or abroad, or from public or private research centers.
L'archive ouverte pluridisciplinaire HAL, est destinée au dépôt et à la diffusion de documents scientifiques de niveau recherche, publiés ou non, émanant des établissements d'enseignement et de recherche français ou étrangers, des laboratoires publics ou privés. 
Bernicot, J., Goumi, A. \& Bert-Erboul. A. Volckaert-Legrier, O. (accepted, 01/20/2014). How do skilled and less-skilled spellers write text messages? A longitudinal study of sixth and seventh graders. Journal of Computer Assisted Learning.

\section{How do skilled and less-skilled spellers write text messages? A longitudinal study of sixth and seventh graders}

\section{Running title: Text messages in teenagers}

Josie Bernicot $^{a}$, Antonine Goumi ${ }^{b}$, Alain Bert-Erboul ${ }^{a}$ and Olga Volckaert-Legrier ${ }^{c}$

a Université de Poitiers, CeRCA - CNRS, UMR 7295, MSHS - Bâtiment A5 - 5, rue

Théodore Lefebvre - 86000 POITIERS - France josie.bernicot@ univ-poitiers.fr -

alainberterboul@gmail.com

b Université Paris Ouest Nanterre La Défense, CHArt UPO EA 4004 - 200, avenue de la

République - 92001 Nanterre Cedex - France antonine.goumi@u-paris10.fr

c Université Toulouse II - Le Mirail, Octogone-ECCD EA 4156- 5, allée Antonio Machado - 31058 Toulouse Cedex 9 - France olga.volckaert-legrier@ univ-tlse2.fr

Address for correspondence:

Josie Bernicot: Université de Poitiers - CNRS, Centre de Recherches sur l'Apprentissage et la Cognition (CeRCA) - MSHS, Bâtiment A5 - 5, rue Théodore Lefebvre, F-86000 Poitiers, France josie.bernicot@univ-poitiers.fr; Phone: +33 (0)5.49.45.46.10 - Fax: +33 (0)5.49.45.46.16 


\section{Abstract}

The link between students' spelling level and their text messaging practice gives rise to numerous questions from teachers, parents, and the media. A corpus of 4,524 text messages produced in daily life situations by students in sixth and seventh grade $(\mathrm{n}=19,11-12$ years of age) was compiled. None of the participants had ever owned or used a mobile phone before the start of the study; their text messages were collected monthly over the course of a year. The traditional writing level was evaluated by means of both a standardized spelling test and grades in French class at school. The comparison between the group with mobile phones and the control group without mobile phones $(n=30)$ showed no difference between the level of traditional writing at the beginning of the text-message collection and during the collection. The results showed that the correlation between the level of traditional spelling and the density of textisms was dependent upon the type of textisms (consistent/breaking with traditional code), the type of spelling (usage-based/rule-based), the grades in French class, and the duration of text-messaging practice. When these elements are not taken into consideration, the present study reproduces the absence of a correlation between textisms and traditional spelling already shown by previous research. On the whole, students who were skilled or less skilled in traditional writing at the beginning of the text-message collection remained respectively skilled or less skilled throughout the year, despite their text-messaging use (density and type of textisms). The discussion of this study's academic implications tends toward a complementarity between traditional writing and text messaging.

\section{Keywords:}

Text messaging, spelling, textisms, teenagers, mobile phone, French language 


\section{Introduction}

Text messaging from mobile phones just celebrated 20 years of existence on December 3, 2012 - and of exponential growth, especially among adolescents (12-17 years of age). In France, $86 \%$ of adolescents send text messages, claiming they send an average of 435 per week (Bigot \& Croute, 2012). Crystal (2008) and Thurlow and Poff (2013) have described the same type of situation in different countries and different languages. Text messages are written using specific spelling forms (textisms) that differ from traditional spelling (e.g., My smmr hols wr CWOT. B4 we used 2 go2 NY 2C my bro, his GF \& thr 3 :- @ kids FTF. ILNY, it's a gr8 $\mathrm{plc}^{1}$ ). Mobile phones are being given to younger and younger children (Ofcom, 2008). These children are thus learning traditional writing in school at the same time as they are learning text-message writing. This text-message writing "frightens" parents, teachers, and the media and is sometimes blamed for causing learning difficulties (Carrington, 2005). The hypothesis can be made that text messaging practice has a negative influence on writtenlanguage learning at school if text messaging is regarded as an incorrect and degraded form of traditional writing that students would be tempted to use in all circumstances. The usual argument, in line with this hypothesis, is that textisms are being used by students in their school writing. This has sometimes been reported by teachers (Lenhart, Arafeh, Smith, \& Macgill, 2008).

This study takes a different point of view by considering text messaging as a new register of written language (Crystal, 2001; Ravid \& Tolchinski, 2002), within the framework of pragmatic studies, which attempt to relate linguistic productions to the communicative situation in which they are produced (Austin, 1962; Bernicot, Laval, \& Chaminaud, 2007; Clark \& Bernicot, 2008; Grice, 1975; Searle, 1969; Verschueren, 1999). A language register

\footnotetext{
${ }^{1}$ Traditional writing translation: My summer holidays were a complete waste of time. Before, we used to go to New York to see my brother, his girlfriend and their three screaming kids face to face. I love New York. It's a great place (from Crystal, 2008, p. 25).
} 
is defined as the set of structural language markers appropriate for a given social situation: This implies that one does not speak the same way to a friend as to an unknown adult, at home versus in the classroom, etc. In the same way, one does not write a text message to a friend in the same way that one would write a summary of the last geography lesson at school. The link between structural markers and social situation is conventionally defined. Working with children between the ages of 11 and 12 is of particular interest: From the point of view of traditional writing, they have benefited from a complete - though not yet stabilized - learning process, but with regard to text messaging, they are merely beginning. If text messaging and traditional writing are considered as two registers, the acquisition of which is dependent on symbolic abilities, the following hypothesis can be made: At the start of text-messaging use, a good traditional spelling level will be linked to the rapid learning of specific forms of the textmessaging register. Conversely, a poor traditional spelling level will be linked to a slower learning of the specific forms of the text-messaging register. Once the text-messaging register has taken hold - after several months of text messaging practice - the link between traditional spelling and text-message spelling will no longer exist, as each register will have its own specific application to social situations. The present study tested this hypothesis by using a large corpus of nearly than 5,000 text messages produced in daily-life situations, and by supplementing existing research primarily carried out with English-language participants, except the French-language study of Bouillaud, Chanquoy, and Gombert (2007) and the study of Plester, Lerkkanen, Linjama, Rasku-Puttonen and Littleton (2011), which was in Finnish. 


\subsection{Previous studies}

Previous studies have demonstrated each of the following cases: the absence of correlation between the density of textisms and the traditional spelling level, the absence of effect of text messaging on spelling, a positive correlation indicating that a high density of textisms was linked to a good level of spelling, and the converse. The density of textisms was the essential index used to evaluate the spelling forms used in text messaging: A textism was defined as a change in the spelling form of a word as compared to traditional writing and the density of textisms was equal to the number of changes divided by the total number of words in the text message. Appendix A presents a synthesis of previous research.

\subsubsection{Absence of correlation between density of textisms and traditional spelling level}

Plester, Wood, and Joshi (2009) gave 10 daily life scenarios (e.g., telling a friend you'll be late to class because of a bus that didn't stop for you, or telling your mother that you forgot to buy dog food) to children (mean age: 10 years 7 months) and asked them to write down the messages they would have written on their mobile phones. The participants took the British Ability Scales II (Elliot, Smith, \& McCulloch, 1996) spelling subtest. The average age at which these participants had received their first mobile phone was 9, and they had approximately 1.5 years of text-messaging experience. The density of textisms produced in these messages was .34 . The textism categories that were most frequently used were simplifications (accent stylizations) that preserved the pronunciation of the spoken language (e.g., afta for after) and substitutions of a group of letters by a letter or a number homophone (e.g., $\mathrm{C} \mathrm{U}$ for see you or 2 moro for tomorrow). The density of textisms was not correlated with the spelling score. Plester, Lerkkanen, Linjama, Rasku-Puttonen, and Littleton (2011) analyzed two types of text messages: natural and spontaneous text messages (that the students 
copied onto paper from their mobile phones) and text messages that were elicited in experimental conditions following the scenarios of Plester et al. (2009). The participants were Finnish-speaking children between the ages of 9 and 11 (mean age: 10 years 7 months). The authors compiled the spelling results measured by means of a standardized test (Lukilasse Graded Word Spelling Test, Häyrinen, Serenius-Sirve, \& Korkman, 1999). The average age of acquiring a mobile phone was 7 years 3 months and the participants therefore had approximately 2 to 4 years of experience. The average density of textisms was .48 for the natural text messages and .36 for the elicited text messages. Simplifications (accent stylizations) that preserved spoken Finnish pronunciation far outweighed all the other categories. The substitution of a group of letters by a number or a letter homophone never appeared at all. The most commonly used types of textisms varied from one language to another. There was no correlation between the density of textisms (written in natural or elicited conditions) and the spelling score on the standardized test. The authors confirmed this result by creating two groups: heavy textism users vs. light textism users with regard to the median. The spelling scores of these two groups did not significantly differ.

\subsubsection{Absence of effect of text messaging on traditional spelling}

Kemp and Bushnell (2011) carried out a study on students between the ages of 10 and 12 (mean age: 11 years 6 months). The participants were asked to write a message on a mobile phone in text-messaging language: The message was dictated by a researcher and the participants were asked to imagine that they were sending it to a friend (e.g., When will we see you tonight? Because someone left a message about your friend being sick. Are you sick too?). The participants, who had owned a mobile phone for nearly 2 years, retained their writing habits of writing on a mobile phone: $52 \%$ used predictive text, about $30 \%$ were multipress texters, and $14 \%$ were non-texters. While carrying out the task, the multi-press texters 
had the highest density of textisms (.48). The spelling results were evaluated by a subtest of the Wide Range Achievement Test (Wilkinson \& Robertson, 2006); there was no difference in the results with regard to the typical manner of writing on a mobile phone (predictive/multi-press/non-texter). In other words, the participants who were skilled at multipress texting and who used more textisms than the other two groups were no different in terms of their traditional spelling scores. Wood, Jackson, Plester, and Wilde (2009) studied the impact of having a mobile phone on the development of spelling ability in students between the ages of 9 and 10 who had never before had access to a mobile phone. The researchers gave one group mobile phones for 9 weeks while the control group remained without mobile phones. The students were allowed to send text messages from every Friday evening until Sunday evening. The researchers collected the mobile phones every Monday morning: They manually transcribed the text messages that the participants had sent over the weekend. The spelling abilities of the two groups had been evaluated using the subtest of the British Ability Scales II (Elliot et al., 1996). The authors determined that before and after the 9-week period, no significant difference could be seen between the spelling levels of two student groups (with or without mobile phones). Text messaging practice had therefore not had an effect on the students' spelling skills.

\subsubsection{Positive correlation between the density of textisms and the level of traditional spelling}

Bouillaud, Chanquoy, and Gombert (2007) compared two dictations (a traditional dictation and a text-message dictation for which the instruction was to write in text-message style) written by students between the ages of 10 and 12 . The participants also filled out a questionnaire whose objective was to evaluate their practice of new communication technologies. The questionnaire was correlated neither with the text-message dictation, nor 
with the traditional dictation. The text-message dictation was positively correlated with the classic dictation: Good results in the classic dictation were linked to a high use of textisms in the text-message dictation, and conversely. Plester, Wood, and Bell (2008) asked students between the ages of 10 and 11 to transcribe, by means of a pencil-and-paper exercise, messages from standard English to text-message English. All of the participants had taken the British Ability Scales II (Elliot et al., 1996) spelling subtest. The average age at which the participants had been given their first mobile phone was 9 years 6 months: Therefore, the participants had between 6 months and 1 year 6 months of experience. The transcriptions were coded into five textism categories: (1) rebus or letter/number homophones (C U L8R); (2) other phonological reductions (nite, wot, wux); (3) symbols (\& @ 1); (4) acronyms (WUU2-what you up to); (5) youth code (wanna, gonna, hafta, me bro, dat). The average density of textisms was .50. A positive correlation was found between the density of textisms and the spelling test score: the higher the density of textisms, the higher the level of spelling, and conversely. Out of the five categories that were identified, two were positively correlated with the spelling test: the "other phonological reductions" and the "youth code". Other research has examined text messages that were spontaneously produced by participants during their everyday activities. In one study, Wood, Jackson, Hart, Plester and Wilde (2011a) used the experimental paradigm of Wood et al. (2009) to carry out a longitudinal (i.e., month-bymonth) 10-week study of 9- to 10-year-old students (mean age: 9 years 10 months) who had never owned a mobile phone. The participants were given access to mobile phones (and could send text messages) on weekends and during half-term break. The researchers took back the mobile phones every Monday, when they transcribed by hand the text messages the participants had sent. All of the participants (a group with mobile phones and a control group without mobile phones) were evaluated by the British Ability Scales II (Elliot et al., 1996) subtest. No difference was shown between the scores of the two groups, neither on the pre-test 
preceding the 10 -week period, nor on the post-test following this period. In the group that had mobile phones, the density of textisms remained stable throughout the study (.129 after week 1 , and .120 at the end of week 10). The average density of textisms was positively and significantly correlated with the spelling scores. Moreover, the value of the correlations increased throughout the study $(r=.28$ on the pre-test and $r=.39$ on the post-test). For students with mobile phones, then, a high density of textisms was linked to good spelling scores, and conversely. In a different study, Wood, Meachem, Bowyer, Jackson, TarczynskiBowles, and Plester (2011b) recorded the density of textisms produced by students between the ages of 8 and 12 (mean age: 10 years 7 months) at the beginning and the end of one school year. All of the participants had their own mobile phones, with 8 years 1 month as the average age of acquiring the phone: Therefore, the participants had approximately 2 years 6 months of experience. The spelling abilities of the participants were evaluated by means of the British Ability Scales II (Elliot et al., 1996) subtest before the text messages were collected and at the end of the school year. The children were asked to provide a sample of the messages they had sent at two points in time: the beginning of the school year and the end of the school year. The results showed that the average ratio of textisms rose from .33 to .40 between the beginning and the end of the school year. This slight increase masks the decreases at 8-9 years of age and at 11-12 years of age that remain to be explained. At both the beginning (T1) and the end (T2) of the year, the ratio of textisms was greater for the 11- to 12-year-olds than for the 8- to 9-year-olds (.42/.27 and .33/.074, respectively). The participants' spelling level remained stable from $\mathrm{T} 1$ to $\mathrm{T} 2$. The correlations between the density of textisms and the spelling level were positive and significant at $\mathrm{T} 1$ and $\mathrm{T} 2$. A high density of textisms is therefore linked to good spelling scores, and conversely. 
Previous studies have focused on children and young adolescents between the ages of 8 and 12. Diverse methods have been used, from natural data collection to the simulation of writing words in text-message language in a paper-and-pencil situation. The density of textisms that resulted was variable: from .074 to .53 . How long the participants had been practicing text messaging was also variable: never before, for a few months, for 1 year, 2 years, or for 4 years. The longitudinal method necessary to comprehend the acquisition process has not been used, except in the research of Wood et al. (2009), Wood et al. (2011a) and Wood et al. (2011b). It should be noted that in the first two cases, the study period was relatively short ( 9 and 10 weeks) and in the last case, the study period was one school yearbut there the text-messaging samples are only available for the beginning and the end of the year.

\subsection{Study objectives}

In order to go further in understanding the link between textisms and traditional spelling, a method must be used that allows reliable determination of the density of textisms truly used by the texters: The present study focused on children between the ages of 11 and 12. The methodology of this study enabled text messages to be collected from everyday life situations. The collection was carried out in a longitudinal manner (month by month) over a long period (12 months) with children who had no text-messaging experience prior to the start of the study. This allowed several things to be accomplished: to study the process by which text-message types evolve, to control the duration of text-messaging practice, and to evaluate the link with traditional spelling according to the duration of text-messaging practice. Finally, different types of textisms were examined. This method was initiated in English by Plester et 
al. (2008) who showed that the positive correlations with the spelling score only concerned two kinds of textisms: the "other phonological reductions" and the "youth code".

Where the French language is concerned, Bernicot, Volckaert-Legrier, Goumi, and Bert-Erboul (2012a) proposed two textism categories that are defined by their relationship with traditional writing: a) textisms that are consistent with the traditional written code of grapheme-phoneme correspondence, i.e., the spelling changes do not modify the phonology (pronunciation) of the words and are created with graphic forms existing in traditional writing (e.g., in French donné for donner, koi for quoi, and in English, hav for have, wen for when); b) textisms which break with the traditional code of grapheme-phoneme correspondence, i.e., spelling changes that modify the phonology (pronunciation) of words and/or are created using graphic forms that do not exist in traditional writing (e.g., in French, twa for toi, pk for pourquoi, and in English, C U for see you, sn for soon). From a cognitive standpoint, the first case is a different application of the same set of rules, while the second case involves the invention of new rules. We hypothesized that children would produce both types of textisms (consistent and breaking with the traditional written code) (Hypothesis 1). In addition, textisms breaking with the code will increase more with practice than textisms consistent with the traditional written code (Hypothesis 2).

Textisms that break with the traditional code are the most specific of the text-messaging register. Therefore, we hypothesized that, early on in text-messaging practice, a positive correlation would be shown between the density of textisms breaking with the traditional code and the spelling level (Hypothesis 3). This correlation should disappear after one year of use when the participants had become accustomed to the specificities of the text-message register (Hypothesis 4). No correlation between the density of textisms consistent with the traditional code and the spelling level would be shown (Hypothesis 5). The sometimes contradictory results of previous studies are undoubtedly due, on the one hand, to the type of textism not 
being taken into account when analyzing the results (except by Plester, Wood, \& Bell, 2008), and, on the other hand, to the duration of text-messaging practice not being taken into account (except by Wood et al., 2009 and Wood et al., 2011a).

\section{Method}

\subsection{Participants}

Nineteen adolescents in sixth and seventh grades participated in the study: 10 girls and 9 boys (mean age $=11.79$ years, $S D^{2}=.59$ of a year). They were recruited from a public junior high school located in a town in the Poitou-Charentes region of France. Students who had never owned or used a mobile phone were invited to participate in the study. The proposal was as follows: to be given access to a mobile phone for one year, free of cost, with the agreement to "donate" at least 20 text messages (written by the students themselves) per month to the research team. The research team guaranteed the students' anonymity at every stage of the study. The students and their parents provided their written consent and agreement. All of the participants were from middle-class backgrounds, of legal school age, and native French speakers.

The control group was made up of thirty adolescents having never owned a mobile phone and having never sent text messages. This group without mobile phones was made up of 11 girls and 19 boys (average age $=11.93$ years, $S D=.59$ of a year) and was recruited from the same junior high school and the same classes as the group that did have mobile phones.

\footnotetext{
${ }^{2} \mathrm{SD}:$ Standard Deviation
} 


\subsection{Materials}

The materials comprised Sony Ericsson model J132 or Alcatel model OT-303 mobile phones (French models). These two analogous mobile phone models did not have an alphanumeric keyboard and were not flip mobile phones. So as to control and homogenize the text-message sending conditions of all the participants, the T9 key, which enabled predictive text and access to a dictionary, was deactivated. All of the text messages in our corpus were written in multi-press mode. There were two types of card for reloading the mobile phones: cards valid for one month equivalent to 30 minutes of voice communication or 150 text messages; and cards valid for 5 days with unlimited text messages. A $3 G$ key and the Vodafone Mobile Connect software installed on a computer allowed the research team to receive the text messages which were "donated" each month by the participants.

\subsection{Procedure}

\subsubsection{Text-message collection}

At the beginning of each month, the participants' mobile phones were automatically credited with a sum of 15 euros, the equivalent of 30 minutes of voice communication or 150 text messages. Once per month, the participants' mobile phones were also credited with the sum of 5 euros, allowing an unlimited number of text messages to be sent over a period of 5 days. It was during this period that the participants were to send at least 20 text messages to the research team, freely chosen from the text messages that they had sent throughout the month and that they had written themselves. Via the 3G key, these text messages were received onto a computer using the Vodafone text message software. A "cut-and-paste" procedure of this software enabled the text messages to be entered into the cells of an Excel ${ }^{\mathrm{TM}}$ 
workbook. This procedure was repeated for 12 months. To our knowledge, for ethical reasons, all previous research carried out with natural data allowed participants, in one way or another, to choose the messages to which the researchers could have access. Considering our collection method - technically simple and free of cost-it seems to us that the risk of systemic bias over one year with 19 participants is quite small. The researchers' access to all of the participants' messages, besides the difficulty of maintaining a relationship of trust throughout the year, could have brought about other kinds of biases: the deletion of the messages or the sending of messages from a different mobile phone.

The participants respected their agreement by providing a total of 4,524 text messages ${ }^{3}$ : on average, per participant, 19.84 text messages $(S D=3.02)$ per month and 238.10 text messages $(S D=36.24)$ for the year. The data collection took place over the 2009-2010 school year. As an example, Appendix A presents the text messages (with their original form in French and their transcribed form in traditional French) of participant no. 1 for month 12.

\subsubsection{Evaluation of traditional writing level}

At the ninth month of the text-message collection, the group with mobile phones and the group without mobile phones took a standardized spelling test from the ANALEC (Analysis of reading ability from 8 years old to adulthood, Inizan, 1998). This test included a classic sixline dictation that resulted in a usage-based spelling score (from 0 to 28) and a rule-based spelling score (from 0 to 16). Usage-based spelling involves the invariable part of the word (e.g., in French, un appel always takes a double "p"; in English, to call is always written with a double "l") while rule-based spelling involves the part of the word that varies with its grammatical form (e.g., in French, the first and the second person of conjugated verbs: je chante/tu chantes; in English, the adverb/plural possessive pronoun: there/their). The test also

\footnotetext{
${ }^{3}$ All of the text messages sent by the participants were taken into consideration, except for the text messages which were "chain letters" or "spam" (by definition not written by the participants themselves).
} 
included a silent dictation (to write beneath pictures the name of what was shown) with a score of 0 to 18 . A total score was calculated, with a minimum score of 0 and a maximum score of 62 .

For the group with mobile phones, each participant's grades in French class at school were also collected for each of the 4 trimesters during which text-messages were collected. For the control group "without mobile phones", only the first three trimesters were taken into account, since after this date we were unable to ensure that these students had not acquired or had not used a mobile phone. Each trimester, the French-class teacher gave a grade (from 0 to 20) to each student: The grade resulted from the combined grades in dictation, grammar, writing, and classical text recitation (poetry or theater). This was a non-standardized grade since the graded exercises varied from one teacher to another and from one trimester to another. However, within the same school, and in similar class levels (sixth and seventh grades), this grade provided a good academic evaluation of the student's traditional writing level.

\subsection{Coding of the textisms}

Three text-message indexes were considered: length, type of textisms, and density of textisms. The length corresponded to the number of characters, including spaces (by definition the value of this index varied between 1 and 160) and the number of words (defined as a letter string with a space on either side). While text-message length was not an index upon which the hypotheses of this study were based, it provided a precise description of the object of the study analyses. A textism was defined as a change in a word's spelling form as compared to traditional writing. For each text message, the density of textisms was equal to the number of changed words divided by the total number of words in the text message. 
The coding of the textisms was based on both English-language analysis grids (Grinter \& Eldridge, 2003; Plester et al., 2009; Thurlow \& Brown, 2003; Tagg, Baron, \& Rayson, 2012) and French-language analysis grids (Anis, 2007; Fairon, Klein, \& Paumier, 2006). Panckhurst (2010) showed the particularities of French (in text-message language) as compared to Italian and Spanish. Dürscheid \& Stark (2011) and Stark (2011) studied the morphosyntactic variation in Swiss-French text messages by comparing them with other languages spoken in that country (German, Italian, and various dialects). As mentioned in the "Objectives" section (1.2.), two major types of textisms were identified with regard to their consistency or their breaking with the traditional written code (Bernicot, Volckaert-Legrier, Goumi, \& Bert-Erboul, 2012a). The different subcategories with examples and equivalences between French and English can be found in Appendix B.

In the corpus used for this study, all of the categories of Thurlow and Brown (2003) were identified, with the exception of "G-clippings", which are specific to English. The "agglutinations" category was highlighted as it has no equivalent in the classification of Thurlow and Brown (2003): Agglutinations are words written one after the other without a space in between ("jtadore" [iloveyou] instead of "je t'adore" [i love you]). A coderagreement index was measured from the 250 randomly selected messages that contained 940 textisms. The index was defined as being equal to the number of textisms coded in the same way by the two coders, divided by the total number of textisms coded. For the coding of the different types of textisms according to the categories of the present study, the inter-coder agreement value was nearly maximal (99.68\%). 


\section{Results}

The results were analyzed in three stages: text messages, traditional writing, and the link between text messages and traditional spelling. The results of the 12 months were grouped into 4 trimesters, so as to be in line with the progression of the school year.

\subsection{Text messages}

For the variables dealing with message length and the density of textisms, by considering the participants as the random variable, the analysis of the results was carried with a one-factor ANOVA: text-message use (trimesters 1 to 4). The differences were considered significant at .05 .

\subsubsection{Text-message length}

For the average number of characters (including spaces) by trimester and by participant, $F(3,54)=1.31, p=0.28$, as well as for the average number of words, $F(3,54)<1$, the effect of practice was not significant. On average, the participants produced messages containing 29.74 characters and 7.05 words.

\subsubsection{Evolution of the density of textisms in text messages with use}

The dependent variable was the average density of textisms (the total number of textisms divided by the number of words per message) by trimester and by participant. The effect of use was significant, $F(3,54)=7.50, p<.0003, \eta^{2}=.29$, (cf. Figure 1 ). The density of textisms increased with the trimesters of use. Planned comparisons highlighted a significant 
difference between trimesters 1 and $2, F(1,18)=20.02, p<.0003$, and then non-significant differences between trimesters 2 and 3 and trimesters 3 and $4, F(1,18)<1$.

\section{Insert Figure 1}

\subsubsection{Different types of textisms in text messages and their evolution with practice}

Table 1 shows the overall distribution of the different types of textisms. The average proportion of textisms was .52 , signifying that, in a given text message, slightly more than half of the words produced by the participants showed a change as compared to traditional spelling and slightly less than half showed no change. Out of the words containing textisms, half (.26) were consistent with traditional code and the other half (.26) broke with this code. For the textisms that were consistent with traditional code, simplifications made up the largest proportion (.23). For textisms that broke with the traditional code, graphemes leading to a phonological modification made up the largest proportion (.13).

\section{Insert Table 1}

With regard to the average density of textisms consistent with the traditional code (number of textisms consistent with the code divided by the number of words per message) by trimester and by participant, the effect of practice was not significant, $F(3,54)=2.15, p=$ 0.10, (cf. Figure 1). The participants produced messages containing a density of textisms of .26.

In terms of the average density of textisms breaking with the code by trimester and by participant, the effect of practice was significant, $F(3,54)=4.21, p<.009, \eta^{2}=.18$, (cf. Figure 1). The density of textisms increased with the trimesters of practice. Planned 
comparisons revealed a significant difference between trimesters 1 and 2, $F(1,18)=11.75, p<$ .003 , and non-significant differences between trimesters 2 and 3 and trimesters 3 and 4, $F(1,18)<1$.

\subsection{Traditional writing}

We began by comparing the group that had mobile phones with the group that did not have mobile phones using two indices: the grades in French at school and the results on the ANALEC standardized spelling test (Inizan, 1998). Table 2a shows the grade in French for the two groups for trimesters 1, 2, and 3. For each trimester, the grades were analyzed using a one-factor ANOVA (group: with mobile phones/without mobile phones). The group effect was never significant (trimester 1 , trimester 2 , trimester 3 : $\mathrm{F}<1$ ). Table $2 \mathrm{~b}$ shows the four scores on the ANALEC spelling test (Inizan, 1998) for the group with mobile phones and for the group without mobile phones. The two groups took the test at the same moment in time, which, for the group with mobile phones, was the ninth month of text-message practice. Each of the scores was analyzed using a one-factor ANOVA (group: with mobile phones/without mobile phones). The group effect was never significant (for usage-based spelling, rule-based spelling, silent dictation, total score: $\mathrm{F}<1$ ). The results, as compared to the ANALEC test standard level for 12-year-olds, were on par with a slightly higher norm in usage-based spelling and silent dictation (equivalent to $60^{\text {th }}$ percentile), and a slightly lower norm in rulebased spelling (equivalent to $40^{\text {th }}$ percentile).

Insert Table 2 
An analysis was carried out on the correlation (Bravais Pearson's $r$ ) between the grades obtained in French class each trimester; the trimesters were considered two by two (cf. Table 3). For each of the two groups (with/without mobile phones), all of the combinations resulted in significant and positive correlations. An analysis was also carried out on the correlation between the ANALEC spelling test scores and the grades in French class throughout the trimesters of the text-message collection. For the two groups, the total ANALEC score was positively correlated with the grades in French class for each trimester (cf. Tables 4a and 4b): The students whose ANALEC test scores were good also had good French grades, and conversely. Furthermore, for the group with mobile phones, the correlation was also significant for trimesters 1 and 4 for the usage score, for the first 3 trimesters for the rule score, and for trimester 4 for the silent dictation. For the group without mobile phones, the correlations were still significant, except for trimester 2 with the silent dictation. These results attested to the strong link between the ANALEC standardized spelling test score and the traditional spelling level. The results also showed the relative stability of the students' academic level throughout the year.

Insert Table 3 and Table 4

\subsection{Link between text messages and traditional writing}

An analysis was carried out of the correlation (Bravais Pearson's $r$ ) between the density of textisms and the ANALEC spelling test scores over the four trimesters of the text-message collection (cf. Table 5).

The correlations that appeared when considering textisms (all categories combined) were the result of two different modes of functioning. Indeed, the separate analysis of the 
textisms that were consistent and that broke with the code showed that the correlations were not the same for the two types of textisms.

For the textisms that were consistent with the code, no significant correlation was found between the density of textisms and the ANALEC spelling test scores.

For the textisms that broke with the code, a positive and significant correlation was found for the two first trimesters between the density of textisms and the usage score on the ANALEC test. The participants that produced numerous textisms also had a good usage score on the ANALEC test, and conversely. A negative and significant correlation also existed for trimester 4 between the density of textisms and the rule score on the ANALEC test. The participants that produced numerous textisms had a poor rule score on the ANALEC test, and conversely. The positive and significant correlation in trimester 1 between the density of textisms and the overall score on the ANALEC test indicates that participants who produced numerous textisms had a high overall score on the ANALEC test, and conversely.

\section{Insert Table 5}

To take these results to a deeper level with regard to textisms breaking with the code, the density of textisms was first analyzed with a two-factor ANOVA: the participants' level in usage-based spelling on the ANALEC test (equal to or superior/inferior to the median) and practice (trimesters 1 to 4 ). The effect of the participants' spelling level, $F(1,17)=7.38, p<$ $.01, \eta^{2}=.30$, and the effect of the participants' practice, $F(3,51)=5.31, p<.003, \eta^{2}=.28$, were significant, as was the interaction between the two factors, $F(3,51)=3.04, p<.04, \eta^{2}=$ .15, (cf. Figure 2). The effect of practice was not the same for the two groups: The participants who had a good score in usage-based spelling produced a greater density of textisms early on in their mobile phone use (trimesters 1 and 2) than participants with a poor 
usage-based spelling score. The density of textisms of skilled spellers remained stable with mobile phone use, while that of less-skilled spellers increased. The two groups' density of textisms was similar in trimester 4.

Finally, with the density of textisms breaking with traditional code as the dependent variable, a second, two-factor ANOVA was carried out: the participants' level of rule-based spelling on the ANALEC test (equal to or superior/inferior to the median) and practice (trimesters 1 to 4 ). The effect of practice, $F(3,51)=6.66, p<.0007, \eta^{2}=.28$, was significant, as was the interaction spelling level $\mathrm{x}$ practice, $F(3,51)=3.14, p<.03, \eta^{2}=.15$, (cf. Figure 2). Again, the effect of practice was not the same for the two groups: The participants with a good rule-based spelling score and those with a poor score produced an analogous density of textisms that progressed over the first three trimesters. From trimester 3 to trimester 4 , the density of textisms of the skilled spellers remained stable while that of the less-skilled spellers increased significantly.

\section{Insert Figure 2}

\section{Discussion}

The data for this study stemmed from a corpus of 4,524 text messages collected over one year from 19 students in sixth and seventh grade (11-12 years of age). A synthesis of these results and the previous research is presented in Appendix A. The text messages, which were produced spontaneously in everyday-life situations, had a stable average length throughout the year of 7 words, 30 characters. In a previous study carried out by Bernicot, Volckaert-Legrier, Goumi, and Bert-Erboul (2012b) and by Goumi, Volckaert-Legrier, Bernicot, \& Bert-Erboul (2011), 15- to 18-year-old adolescents were shown to produce 
messages that were 20 words, 100 characters in length. Message length thus may be linked to age, but also to the type of communication device being used: a small screen only contains 160 characters. Like 15- to 18-year-old adolescents, 11- to 12-year-old children are able to write much longer texts, but in the particular situation of text messaging, they write short messages, not fully using the 160 available characters. With regard to the density of textisms, a result of .52 was obtained, corresponding to the highest results of previous studies, such as that of Plester et al. (2011) in spontaneous production, or that of Kemp and Bushnell (2011) and of Plester, Wood, and Bell (2008) in an experimental situation. When writing a text message, a child of 11 to 12 years of age follows traditional spelling for half of the words, and doesn't follow it for the other half. It should be noted that this result was obtained in multipress mode. Kemp and Bushnell (2011) found that, in a situation of elicited text messages, the children writing in multi-press mode had a higher density of textisms (.48) than children writing in predictive mode (.27).

\subsection{The link between textisms and traditional spelling}

First of all, it should be emphasized that the comparison between the group with mobile phones and the group without mobile phones showed no difference with regard to French grades in school: the level was identical in trimester 1 (starting point of text-message practice for the group with mobile phones) and remained identical throughout trimesters 2 and 3. Textmessaging practice, therefore, did not modify the level of French at school. The fact that there was no difference between the two groups on the ANALEC (Inizan, 1998) standardized spelling test, after nine months of text-messaging practice for the group with mobile phones, is also consistent with an absence of effect of text-messaging practice on the students' spelling level. In accordance with the hypothesis of this study, children produced two types of 
textisms: those consistent with and breaking with the traditional written code (Hypothesis 1). These two types of textisms were produced in equal proportion (.26) and did not evolve in the same manner with practice: Only the textisms that broke with the code increased with practice (Hypothesis 2). Specific to the text-message register, the textisms that broke with the code were learned over the first two trimesters of use, and then their proportion remained stable in trimesters 3 and 4 .

Again, in accordance with the hypothesis of this study, the link between the level of traditional spelling and textisms varied with the type of textisms being considered. No correlation was found between the various spelling scores and textisms consistent with the code (Hypothesis 5). Positive correlations existed in trimesters 1 and 2 between the usagebased spelling score and textisms that broke with the code (Hypothesis 3); these correlations disappeared in trimesters 3 and 4 (Hypothesis 4). The distribution of the students into two groups (skilled/less skilled in usage-based spelling) showed that students who were less skilled in usage-based spelling learned textisms that broke with the code more slowly than students with good usage-based spelling. The skilled group started out with a high level of textisms that broke with the code (.26), while the less-skilled group began at .16 and did not catch up with the skilled group until trimester 4. This result confirms the pertinence of considering text messages and traditional writing as two registers whose acquisition is dependent on the same symbolic abilities. Data provided by Coe \& Oakhill (2011) about reading have revealed similar results: The skilled readers used more textisms in their written text messages and were faster at reading all the messages than less-skilled readers. From the very first trimester of text-message use, the students who were skilled in traditional writing used forms that were specific to the text-message register (textisms breaking with the traditional code) while at the same time remaining skilled students in traditional writing 
throughout the entire year. They therefore applied each register to the appropriate social situation.

One result should be highlighted, as it was not predicted by the hypotheses of this study: the negative correlation in trimester 4 between the rule-based spelling score and textisms that broke with the traditional code. The distribution of the students into two groups (skilled/less skilled in rule-based spelling) showed that the density of textisms breaking with the traditional code increased for both groups over the first three trimesters. In trimester 4 , the density of textisms breaking with the code remained stable for the students who were skilled in rulebased spelling, while it increased for students who were less skilled in rule-based spelling (.35 for the less skilled spellers and .26 for the skilled spellers). A complementary study of students who have more than one year of text-messaging experience will be necessary to interpret these data.

This study demonstrated the difficulty of answering the question of the link between textisms and traditional spelling in simple terms. The response depends on the type of textisms (consistent with/breaking with the traditional code), the type of spelling (usagebased/rule-based), the level of traditional writing in school (skilled/less-skilled spellers) and when exactly text messaging was learned (duration of practice). When these elements are not taken into consideration, the present study reproduces the absence of a correlation between textisms and traditional spelling already shown by Plester, Wood and Joshi (2009) and Plester et al. (2011). When these elements are considered, the correlation can be absent (textisms consistent with the traditional spelling code), positive (textisms breaking with the traditional spelling code and usage-based spelling in the early stages of text-message use), or negative (textisms breaking with the traditional written code and rule-based spelling after one year of text-message use). 


\subsection{Academic implications}

The first academic implication is that teachers, whose role it is to teach traditional written language to students in sixth and seventh grade, have no reason to be "afraid" of text messaging or to perceive it as a threat. Both skilled students and less-skilled students in traditional writing produced the same number of textisms consistent with the traditional code (e.g., hav for have, wen for when). Skilled students (in usage-based spelling) at the very beginning of the text-message learning process produced more textisms that broke with the traditional code (e.g., C U for see you, sn for soon) than less-skilled students who joined them at the end of the learning process. The less-skilled students (in rule-based spelling) who were at the end of the text-message learning process used more textisms that broke with the traditional code than the skilled students. The high and positive correlations between the grades in French class over the four trimesters indicate that the students' relative level remained stable, no matter their text-message production. The skilled students who produced numerous textisms breaking with the traditional code in trimesters 1 and 2 did not become less-skilled students in trimesters 3 and 4. The less-skilled students who did not produce many textisms breaking with the traditional code in trimesters 1 and 2 did not become skilled students in trimesters 3 and 4. Furthermore, the less-skilled students that produced numerous textisms breaking with the traditional code in trimester 4 were already less-skilled students in trimester 1 .

The second academic implication is that text messages present a new and additional manner in which to practice writing - up until now, 11- to 12-year-old children were limited to the school context and a few postcards when it came to writing. So far, this study only focused on the $52 \%$ of words in the text messages that contained textisms. However, the other $48 \%$ of words that were written according to traditional rules also need to be considered. It 
should be emphasized that new technologies are providing students with additional opportunities to practice written language, opportunities that have only recently emerged: email, instant messaging, discussion or online homework help forums, blogs, and social networks such as Facebook and Twitter (Crystal, 2008; Ellison, Steinfield, \& Lampe, 2007; Fernandez \& Yuldashev, 2011; Herring, Stein, \& Virtanen, 2013; Puustinen , Bernicot, \& Bert-Erboul, 2011; Puustinen, Volckaert-Legrier, Coquin, \& Bernicot, 2009; Savas, 2011; Volckaert-Legrier, Bernicot, \& Bert-Erboul, 2009).

The third academic implication is that text messages could be used as an ally for learning at school, based on three facts: 1) Students use this form of communication (both writing and reading) easily and with enthusiasm; 2) No study has shown a negative link between text-messaging and the command of traditional writing; 3) A significant number of students own mobile phones, one of the least expensive new technologies. For all of these reasons, mobile phones and text messaging could be used as academic learning aids, no longer reserved simply for the exchange of information with friends and family. Worthwhile attempts have already been made in this direction with students at the university level, referred to as mLearning, for mobile learning (Yenglin, Karahoca, Karahoca, \& Uzunboylu, 2011). For example, the teacher sends the students a text message containing the vocabulary words to be learned in a second language $(\mathrm{Lu}, 2008)$ or a multiple-choice questionnaire with regard to a class topic with the students receiving immediate feedback after sending their response (Yenglin et al., 2011), or the instructor encourages students to discuss a compulsory class museum visit by means of text messaging (Holley \& Dobson, 2008). In 2010, UNESCO published a document entitled "mLearning: a platform for educational opportunities at the base of the pyramid", calling for the development of this type of project. 


\subsection{Limits of the research}

The data contributed by the present study dealt with a significant number of text messages $(4,524)$ composed by typical 11 - to 12 -year-old children who were French native speakers in their first year of text-messaging practice. The validity of our results is based on a significant number of messages in total and per participant (238 on average), and on a control and knowledge of the sociological characteristics of the participants that made up a homogeneous group. The sample size of 19 participants, however, must be increased so as to consolidate the results. Complementary studies with younger or older children, and with more text-messaging experience, will be necessary in order to refine the knowledge of the complex relationship between text messaging and traditional writing. The categorization of text messages that are either consistent or break with the traditional code will need to be carried out in languages other than French. Consideration of certain participant characteristics such as gender will also be necessary. Moreover, it would be pertinent to study the connection between other text-message characteristics than textisms (such as the dialogic structure or the social function) with literacy indexes including not only traditional writing, but also reading and cultural and communicative practices. Finally, it should be specified that our study was carried out with analog telephones with a multi-press mode of text input. These mobile phones corresponded to the technology that was accessible to young French junior high students living in a small provincial town at the end of 2010. Our contribution demonstrated the variations in message form that were brought about by the use of this technology as compared to traditional writing. The arrival of smartphones possessing high-performance dictionaries, allowing more than 160 characters, and that are able to translate voice messages into written messages will undoubtedly introduce new variations that will in turn need to be analyzed in future studies. 


\section{Acknowledgements}

The authors would like to thank all the children and parents who participated in this study, and especially the school that collaborated with the researchers. In addition, the authors would like to thank the students who helped with the collection of the data and Martha Randy for translating the paper. This text is dedicated to Lucette Bernicot.

This research was supported by the French National Research Agency project ANR-08COMM-011-01 entitled "Adolescents and Computer-Mediated Writing: Prerequisites, Uses, and Learning" and by the "Centre Henri-Aigueperse / UNSA Éducation" with the assistance of the IRES. 
Appendix A - Synthesis of previous research and research presented in this article

\begin{tabular}{|c|c|c|c|c|}
\hline \multirow[b]{2}{*}{ Papers } & \multirow[b]{2}{*}{ Participants } & \multicolumn{3}{|l|}{ A: Mean Age } \\
\hline & & $\begin{array}{l}\text { Exp: Text-messaging } \\
\text { experience }\end{array}$ & Method & Results \\
\hline \multicolumn{5}{|c|}{ Absence of correlation between density of textisms and traditional spelling level } \\
\hline $\begin{array}{l}\text { Plester, Wood, and } \\
\text { Joshi (2009) }\end{array}$ & $\begin{array}{l}88 \text { English- } \\
\text { speaking } \\
\text { participants }\end{array}$ & $\begin{array}{l}\text { A: } 10 \text { years } 7 \text { months } \\
\text { Exp: } 1 \text { year and } 6 \\
\text { months }\end{array}$ & $\begin{array}{l}\text { Text messages were elicited in experimental } \\
\text { conditions as part of everyday life scenarios. } \\
\text { Spelling skills were assessed by means of a } \\
\text { standardized spelling test. }\end{array}$ & $\begin{array}{l}\text { Density of textisms (mean }=.34 \text { ) was not correlated } \\
\text { with the spelling score. }\end{array}$ \\
\hline $\begin{array}{l}\text { Plester, Lerkkanen, } \\
\text { Linjama, Rasku- } \\
\text { Puttonen, and } \\
\text { Littleton (2011) }\end{array}$ & $\begin{array}{l}65 \text { Finnish- } \\
\text { speaking } \\
\text { participants }\end{array}$ & $\begin{array}{l}\text { A: } 10 \text { years } 7 \text { months } \\
\text { Exp: } 2-4 \text { years }\end{array}$ & $\begin{array}{l}\text { Text messages were collected in natural and } \\
\text { spontaneous conditions and were elicited in } \\
\text { experimental conditions as part of everyday life } \\
\text { scenarios. } \\
\text { Spelling skills were assessed by means of a } \\
\text { standardized spelling test. }\end{array}$ & $\begin{array}{l}\text { Mean density of textisms: } .48 \text { for natural text messages } \\
\text { and } .36 \text { for elicited text messages. } \\
\text { Density of textisms was not correlated with the spelling } \\
\text { score on the standardized test. } \\
\text { No difference in spelling scores between the two } \\
\text { groups (heavy textism users vs. light textism users). }\end{array}$ \\
\hline \multicolumn{5}{|c|}{ Absence of effect of text messaging on traditional spelling } \\
\hline $\begin{array}{l}\text { Kemp and Bushnell } \\
\text { (2011) }\end{array}$ & $\begin{array}{l}86 \text { English- } \\
\text { speaking } \\
\text { participants }\end{array}$ & $\begin{array}{l}\text { A: } 11 \text { years } 6 \text { months } \\
\text { Exp: } 2 \text { years }\end{array}$ & $\begin{array}{l}\text { Text messages were dictated to the participants by } \\
\text { a researcher and written on a mobile phone by the } \\
\text { participants. Three groups of texters: } \\
\text { predictive/multi-press/non-texter. } \\
\text { Assessment of spelling skills by means of a } \\
\text { standardized spelling test. }\end{array}$ & $\begin{array}{l}\text { Mean density of textisms: } \\
.27 \text { for predictive, } .48 \text { for multi-press, } .31 \text { for non- } \\
\text { texter. } \\
\text { No difference in spelling scores with regard to the } \\
\text { density of textisms. }\end{array}$ \\
\hline $\begin{array}{l}\text { Wood, Jackson, } \\
\text { Plester, and Wilde } \\
\text { (2009) }\end{array}$ & $\begin{array}{l}61 \text { English- } \\
\text { speaking } \\
\text { participants }\end{array}$ & $\begin{array}{l}\text { A: } 9-10 \text { years } \\
\text { Exp: Never had } \\
\text { access to a mobile } \\
\text { phone before }\end{array}$ & $\begin{array}{l}\text { Text messages were collected in natural and } \\
\text { spontaneous conditions. } \\
\text { One group had a mobile phone for } 9 \text { weeks while } \\
\text { the control group remained without a mobile } \\
\text { phone. } \\
\text { Assessment of spelling skills by means of a } \\
\text { standardized spelling test. }\end{array}$ & $\begin{array}{l}\text { No difference in spelling scores between the two } \\
\text { groups (with vs. without mobile phones) before and } \\
\text { after the } 9 \text {-week period. }\end{array}$ \\
\hline
\end{tabular}




\section{Positive correlation between the density of textisms and the level of traditional spelling}

\begin{tabular}{|c|c|c|c|c|}
\hline $\begin{array}{l}\text { Bouillaud, Chanquoy, } \\
\text { and Gombert (2007) }\end{array}$ & $\begin{array}{l}144 \text { French- } \\
\text { speaking } \\
\text { participants }\end{array}$ & $\begin{array}{l}\text { A: } 10-12 \text { years } \\
\text { Exp: Not indicated }\end{array}$ & $\begin{array}{l}\text { Two dictations: traditional vs. text-message } \\
\text { dictation. }\end{array}$ & $\begin{array}{l}\text { Text-message dictation was positively correlated with } \\
\text { traditional dictation: good results in the traditional } \\
\text { dictation were linked to a high use of textisms in the } \\
\text { text-message dictation, and conversely. }\end{array}$ \\
\hline $\begin{array}{l}\text { Plester, Wood, and } \\
\text { Bell (2008) }\end{array}$ & $\begin{array}{l}35 \text { English- } \\
\text { speaking } \\
\text { participants }\end{array}$ & $\begin{array}{l}\text { A: } 10-11 \text { years } \\
\text { Exp: Between } 6 \\
\text { months and } 1 \text { year } 6 \\
\text { months }\end{array}$ & $\begin{array}{l}\text { Text messages were elicited through a translation } \\
\text { task (pencil-and-paper exercise): to write } \\
\text { messages from standard English to text-message } \\
\text { English. } \\
\text { Assessment of spelling skills by means of a } \\
\text { standardized spelling test. }\end{array}$ & $\begin{array}{l}\text { Mean density of textisms }=.50 \\
\text { Positive correlation between the density of textisms } \\
\text { and spelling test scores. }\end{array}$ \\
\hline $\begin{array}{l}\text { Wood, Jackson, Hart, } \\
\text { Plester, and Wilde } \\
\text { (2011a) }\end{array}$ & $\begin{array}{l}114 \text { English- } \\
\text { speaking } \\
\text { participants }\end{array}$ & $\begin{array}{l}\text { A: } 9 \text { years } 10 \text { months } \\
\text { Exp: Never had } \\
\text { access to a mobile } \\
\text { phone before }\end{array}$ & $\begin{array}{l}\text { Text messages were collected in natural and } \\
\text { spontaneous conditions. } \\
\text { One group with a mobile phone for } 10 \text { weeks vs. } \\
\text { control group remained without a mobile phones. } \\
\text { Assessment of spelling skills by means of a } \\
\text { standardized spelling test. }\end{array}$ & $\begin{array}{l}\text { Mean density of textisms }=.12 \text {. } \\
\text { No difference in spelling scores between the two } \\
\text { groups (with vs. without mobile phone) before and } \\
\text { after the } 10 \text {-week period } \\
\text { Density of textisms was positively correlated with the } \\
\text { spelling scores. }\end{array}$ \\
\hline $\begin{array}{l}\text { Wood, Meachem, } \\
\text { Bowyer, Jackson, } \\
\text { Tarczynski-Bowles, } \\
\text { and Plester (2011b) }\end{array}$ & $\begin{array}{l}119 \text { English- } \\
\text { speaking } \\
\text { participants }\end{array}$ & $\begin{array}{l}\text { A: } 10 \text { years } 7 \text { months } \\
\text { Exp: } 2 \text { years } 6 \\
\text { months }\end{array}$ & $\begin{array}{l}\text { Text messages were collected in natural and } \\
\text { spontaneous conditions over one year. } \\
\text { Participants had to provide a sample of the } \\
\text { messages sent with their own mobile phones at } \\
\text { the beginning of the school year (T1) and at the } \\
\text { end of the school year (T2). } \\
\text { Assessment of spelling skills by means of a } \\
\text { standardized spelling test. }\end{array}$ & $\begin{array}{l}\text { Density of textisms: } 33(\mathrm{~T} 1) ; .40(\mathrm{~T} 2) \text {. } \\
\text { Spelling scores remained stable from } \mathrm{T} 1 \text { to } \mathrm{T} 2 \text {. } \\
\text { Correlations between density of textisms and spelling } \\
\text { scores were positive at } \mathrm{T} 1 \text { and } \mathrm{T} 2 \text {. }\end{array}$ \\
\hline $\begin{array}{l}\text { Study presented in } \\
\text { this paper }\end{array}$ & $\begin{array}{l}49 \text { French- } \\
\text { speaking } \\
\text { participants }\end{array}$ & $\begin{array}{l}\text { A: } 11-12 \text { years } \\
\text { Exp: Never had } \\
\text { access to a mobile } \\
\text { phone before }\end{array}$ & $\begin{array}{l}\text { Text messages were collected in natural and } \\
\text { spontaneous conditions over one year. Text } \\
\text { messages were collected monthly. } \\
\text { One group with mobile phones vs. control group } \\
\text { without mobile phones. } \\
\text { Assessment of the traditional writing level by } \\
\text { means of a standardized spelling test and by } \\
\text { grades in French class at school. }\end{array}$ & $\begin{array}{l}\text { Mean density of textisms }=.52 . \\
\text { No difference between the group with mobile phones } \\
\text { and the group without mobile phones in terms of } \\
\text { traditional writing level at the beginning of the text- } \\
\text { message collection and during the collection. } \\
\text { Correlation between the level of traditional spelling } \\
\text { and the density of textisms dependent on type of } \\
\text { textisms (consistent/breaking with traditional code), } \\
\text { type of spelling (usage-based/rule-based), grades in } \\
\text { French class, and duration of text-messaging practice. }\end{array}$ \\
\hline
\end{tabular}


Appendix B - Examples of text messages from participant no. 1 for month 12. The participant is a girl aged 12 years 2 months.

\begin{tabular}{|c|c|c|}
\hline $\begin{array}{l}\mathrm{N}^{\circ} \text { text } \\
\text { message }\end{array}$ & Original text message in French & $\begin{array}{l}\text { Text-message transcription in } \\
\text { traditional French and English }\end{array}$ \\
\hline 1 & $\begin{array}{l}\text { Apel moi si tu recoi ce message } \\
\text { emeline }\end{array}$ & $\begin{array}{l}\text { Appelle-moi si tu reçois ce message } \\
\text { Emeline } \\
\text { Call me if you get this message } \\
\text { Emeline }\end{array}$ \\
\hline 2 & Ya rien de drol & $\begin{array}{l}\text { Ya rien de drôle } \\
\text { Nothing funny about that }\end{array}$ \\
\hline 3 & $\begin{array}{l}\text { Jen ai mar mn pere juste psk lordi } \\
\text { lenerve } \mathrm{c} \text { moi quil engueule }\end{array}$ & $\begin{array}{l}\text { J'en ai marre mon père juste parce que } \\
\text { l'ordinateur l'énerve c'est moi qu'il } \\
\text { engueule } \\
\text { I'm sick of it my dad just because the } \\
\text { computer makes him mad he yells at me }\end{array}$ \\
\hline 4 & Cc je voulai prendre de $t$ nouvel & $\begin{array}{l}\text { Coucou je voulais prendre de tes } \\
\text { nouvelles } \\
\text { Hey there I wanted to see how you were } \\
\text { doing }\end{array}$ \\
\hline 5 & $\begin{array}{l}\text { Je c pa psk ma mere es de nui mn pere } \\
\text { du matin et du cou c mon oncle et ma } \\
\text { tata qui von dormir che moi come sa je } \\
\text { serai pa toute seule cet nui donc je c pa }\end{array}$ & $\begin{array}{l}\text { Je sais pas parce que ma mère est de nuit } \\
\text { mon père du matin et du coup c'est mon } \\
\text { oncle et ma tata qui vont dormir chez } \\
\text { moi comme ça je serai pas toute seule } \\
\text { cette nuit donc je sais pas } \\
\text { I don't know because my mom is on } \\
\text { nights my dad on mornings so my uncle } \\
\text { and my auntie are going to sleep over at } \\
\text { my place that way I won't be all alone } \\
\text { tonight so I don't know }\end{array}$ \\
\hline 6 & Je croier que tu devez mapeler & $\begin{array}{l}\text { Je croyais que tu devais m'appeler } \\
\text { I thought you were going to call me }\end{array}$ \\
\hline 7 & Je sui conecter & $\begin{array}{l}\text { Je suis connectée } \\
\text { I'm online }\end{array}$ \\
\hline 8 & $\mathrm{Ba}$ aten jai pa menger & $\begin{array}{l}\text { Bah attends j'ai pas mange } \\
\text { Hey wait I haven't eaten }\end{array}$ \\
\hline 9 & Cc tu fe koi & $\begin{array}{l}\text { Coucou tu fais quoi } \\
\text { Hey there what are you doing }\end{array}$ \\
\hline 10 & $\begin{array}{l}\text { Je croi que jai la gripe (jai de la fièvre } \\
\text { et je tousse bocoup donc jai plus de } \\
\text { voie }\end{array}$ & $\begin{array}{l}\text { Je crois que j'ai la grippe (j'ai de la } \\
\text { fièvre et je tousse beaucoup donc j'ai } \\
\text { plus de voix) } \\
\text { I think I have the flu (I have a fever and } \\
\text { I'm coughing a lot and I've lost my } \\
\text { voice) }\end{array}$ \\
\hline
\end{tabular}


Appendix $\mathrm{C}$ - Examples of different categories of textisms consistent with or breaking with the traditional code of phoneme-grapheme correspondence

Textisms consistent with the traditional code of phoneme-grapheme correspondence

\begin{tabular}{llll}
\hline Categories & Simplifications & Complexifications & Substitutions \\
\hline $\begin{array}{l}\text { Examples (and } \\
\text { transcriptions into } \\
\text { traditional French) }\end{array}$ & $\begin{array}{l}\text { mé (mais), fodra } \\
\text { (faudra), pa (pas), } \\
\text { kel (quel) }\end{array}$ & $\begin{array}{l}\text { on ny va (on y va), } \\
\text { bonne anniversaire } \\
\text { (bon anniversaire) }\end{array}$ & $\begin{array}{l}\text { sa), rentrer } \\
\text { (rentrez), aver (avez) }\end{array}$ \\
\hline English equivalent & $\begin{array}{l}\text { hav (have), ), wen } \\
\text { (when), bothA } \\
\text { (bother) }\end{array}$ & $\begin{array}{l}\text { Shapping (shaping), } \\
\text { leade (lead) }\end{array}$ & $\begin{array}{l}\text { fone (phone), rite } \\
\text { (right) }\end{array}$ \\
\hline
\end{tabular}

Textims breaking with the traditional code of phoneme-grapheme correspondence

\begin{tabular}{|c|c|c|c|c|}
\hline Categories & $\begin{array}{l}\text { New phoneme- } \\
\text { grapheme } \\
\text { correspondences } \\
\text { without } \\
\text { phonological } \\
\text { modification }\end{array}$ & Agglutinations & $\begin{array}{l}\text { Phonological } \\
\text { modifications }\end{array}$ & $\begin{array}{l}\text { Words or } \\
\text { graphic } \\
\text { forms non- } \\
\text { existant in } \\
\text { traditional } \\
\text { French }\end{array}$ \\
\hline $\begin{array}{l}\text { Examples (and } \\
\text { transcriptions into } \\
\text { traditional French) }\end{array}$ & $\begin{array}{l}\text { twa (toi), qe } \\
\text { (que), ri1 (rien), } \\
\text { JeC (je sais) }\end{array}$ & $\begin{array}{l}\text { jtadore (je } \\
\text { t'adore), tsais (tu } \\
\text { sais) }\end{array}$ & $\begin{array}{l}\text { num (numéro), } \\
\text { ex (exercice), } \\
\text { bsx (bisous), cc } \\
\text { (coucou) }\end{array}$ & $\begin{array}{l}\text { blème } \\
\text { (problème), } \\
\text { je kife } \\
\text { (j'aime), ;-) } \\
\text { (smiley } \\
\text { wink) }\end{array}$ \\
\hline English equivalent & $\begin{array}{l}\text { 2day (today), C } \\
\text { U (see you), } 18 \mathrm{r} \\
\text { (later) }\end{array}$ & $\begin{array}{l}\text { Iloveyou } \\
\text { (I love you) }\end{array}$ & $\begin{array}{l}\text { sn (soon), tmrw } \\
\text { (tomorrow), bout } \\
\text { (about) }\end{array}$ & $\begin{array}{l}\text { me bro (my } \\
\text { brother), LO } \\
\text { (hello), } \\
\text { gunna (going } \\
\text { to), >-- } \\
\text { (smiley } \\
\text { flower) }\end{array}$ \\
\hline
\end{tabular}




\section{References}

Anis, Jacques. (2007). Neography - Unconventional Spelling in French SMS Text Messages. In B. Danet \& S. C. Herring (Eds.), The Multilingual Internet - Language, Culture and Communication Online (pp. 87-115). New York: OxfordUniversity Pres.

Austin, J.L. (1962). How to do things with words. Cambridge, Massachusetts: Harvard University Press.

Bernicot, J., Laval, V., \& Chaminaud, S. (2007). Nonliteral language forms in children: In what order are they acquired in pragmatics and metapragmatics? Journal of Pragmatics, 39, 2115-2132. doi: 10.1016/j.pragma.2007.05.009

Bernicot, J., Volckaert-Legrier, O., Goumi, A., \& Bert-Erboul, A. (2012a). SMS experience and textisms in young adolescents: Presentation of a longitudinally collected corpus. Lingvisticae Investigationes, 35(2), 181-198.

Bernicot, J., Volckaert-Legrier, O., Goumi, A., \& Bert-Erboul, A. (2012b). Forms and functions of SMS messages: A study of variations in a corpus written by adolescents. Journal of Pragmatics, 44, 1701-1715.

Bigot, R., \& Croute, P. (2012). La diffusion des technologies de l'information et de la communication dans la société française. Paris: CREDOC.

Bouillaud, C., Chanquoy, L., \& Gombert, J-E. (2007). Cyberlangage et orthographe : quels effets sur le niveau orthographique des élèves de $\mathrm{CM} 2$, 5e et 3e? Bulletin de Psychologie, 60 (6), 553-565.

Carrington, V. (2005). Txting: the end of civilization (again)? Cambridge Journal of Education, 25(2), 161-175.

Clark, E.V., \& Bernicot, J. (2008). Repetition as ratification: how parents and children place information in common ground? Journal of Child Language, 35(2), 349-372.

Coe, J.E.L., \& Oakhill, J.V. (2011). 'txtN is ez $\mathrm{f} u$ no $\mathrm{h} 2 \mathrm{rd}$ ': the relation between reading ability and text-messaging behaviour. Journal of Computer Assisted Learning, 27, 417.

Crystal, D. (2001). Language and the Internet. Cambridge: Cambridge University Press.

Crystal, D. (2008). Txtng: The gr8 db8. Oxford: Oxford University Press. 
Dürscheid, C., \& Stark, E. (2011). sms4science: An international corpus-based texting project and the specific challenges for multilingual Switzerland. In C. Thurlow \& K. Mroczek (Eds.), Digital Discourse. Language in the New Media (pp. 299-320). Oxford: University Press.

Elliot, C. D., Smith, P. , \& McCulloch, K. (1996). British Ability Scales : Second Edition (BAS II). Windsor: NFER-Nelson.

Ellison, N., B., Steinfield, C., \& Lampe, C. (2007). The benefits of Facebook "friends:” Social capital and college students' use of online social network sites. Journal of Computer-Mediated Communication, 12, 1143-1168. doi: 10.1111/j.10836101.2007.00367.x

Fairon, C., Klein, J., \& Paumier, S. (2006). SMS pour la science. Corpus de 30.000 SMS et logiciel de consultation. Louvain-la-Neuve, Presses Universitaires de Louvain.

Fernandez, J., \& Yuldashev, A. (2011). Variation in the use of general extenders and stuff in instant messaging interactions. Journal of Pragmatics, 43(10), 2610-2626. doi: 10.1016/j.pragma.2011.03.012

Goumi, A., Volckaert-Legrier, O., Bernicot, J., \& Bert-Erboul, A. (2011). SMS length and function: a comparative study of 13 to 18 year-old girls and boys. European Review of Applied Psychology, 61(4), 175-184. doi: 10.1016/j.erap.2011.07.001

Grice, P. (1975). Logic and conversation. In P. Cole \& J. Morgan (Eds.), Syntax and Semantics Vol 3: Speech Acts. New York: Academic Press.

Grinter, R, \& Eldridge, M. (2003). Wan2tlk?: Everyday Text Messaging. Paper presented at the CHI 2003 Proceedings of the SIGCHI conference on Human Factors in Computing Systems, Ft. Lauderdale, Florida.

Häyrinen, T., Serenius-Sirve, S., \& Korkman, M. (1999). Lukilasse [The Lukilasse Graded Achievement Package for Comprehensive School Age Children]. Helsinki: Psykologien kustannus.

Herring, S. C., Stein, D., \& Virtanen, T. (2013). Handbook of pragmatics of computermediated communication. Berlin: Mouton.

Holley, D., \& Dobson, C. (2008). Encouraging student engagement in a blended learning environment: The use of contemporary learning spaces. Learning, Media and Technology, 33(2), 139-150.

Inizan, A. (1998). Analyse du savoir-lire de 8 ans à l'âge adulte : ANALEC et la dyslexie. Paris: Editions EAP. 
Kemp, N., \& Bushnell, C. (2011). Children's text messaging: abbreviations, input methods and links with literacy. Journal of Computer Assisted Learning, 27, 18-27.

Lenhart, A., Arafeh, S., Smith, A., \& Macgill, A.R. . (2008). Writing, technology and teens. Retrieved June 18, 2013 from http://www.pewinternet.org/Reports/2008/WritingTechnology-and-Teens.aspx

Lu, M. (2008). Effectiveness of vocabulary learning via mobile phone. National Keelung Vocational High School. Journal of Computer Assisted Learning, 24, 515-525. doi: 10.1111/j.1365-2729.2008.00289.x

Ofcom. (2008). Media literacy audit: Report on UK children's media literacy. Retrieved June 18, 2013 from http://stakeholders.ofcom.org.uk/market-data-research/medialiteracy/archive/medlitpub/medlitpubrss/ml_childrens08/

Panckhurst, R. (2010). Texting in three European languages: does the linguistic typology differ? Paper presented at the Colloque Imean, University of the West of England, Bristol, April.

Plester, B., Lerkkanen, M.-K., Linjama, L.J., Rasku-Puttonen, H., \& Littleton, K. (2011). Finnish and UK English pre-teen children's text message language and its relationship with their literacy skills. Journal of Computer Assisted Learning 27, 37-48. doi: 10.1111/j.1365-2729.2010.00402.x

Plester, B., Wood, C., \& Bell, V. (2008). Txt msg n school literacy: does texting and knowledge of text abbreviations adversely affect children's literacy attainment? Literacy, 42(3), 137-144. doi: 10.1111/j.1741-4369.2008.00489.x

Plester, B., Wood, C., \& Joshi, P. (2009). Exploring the relationship between children's knowledge of text message abbreviations and school literacy outcomes. British Journal of Developmental Psychology, 27, 145-161. doi: 10.1348/026151008X320507

Puustinen, M., Bernicot, J., \& Bert-Erboul, A. (2011). Written Computer-Mediated Requests for Help by French-Speaking Students : An Analysis of Their Forms and Functions. Learning and Instruction, 21, 281-289. doi: 10.1016/j.learninstruc.2010.07.005

Puustinen, M., Volckaert-Legrier, O., Coquin, D., \& Bernicot, J. (2009). An analysis of students' spontaneous computer-mediated help seeking: A step toward the design of ecologically valid supporting tools. Computers and Education, 53, 1040-1047. doi: 10.1016/j.compedu.2008.10.003

Ravid, D., \& Tolchinski, L. (2002). Developing linguistic literacy: a comprehensive model. Journal of Child Language, 29(2), 417-447. 
Savas, P. (2011). A case study of contextual and individual factors that shape linguistic variation in synchronous text-based computer-mediated communication. Journal of Pragmatics, 43, 298-313. doi: 10.1016/j.pragma.2010.07.018

Searle, J.R. (1969). Speech Acts. Cambridge, MA, : Cambridge University Press.

Stark, E. (2011). La morphosyntaxe dans les SMS suisses francophones: Le marquage de l'accord sujet - verbe conjugué. Linguistik Online, 48(4), 35-47. doi: 10.5167/uzh50915

Tagg, C., Baron, A., \& Rayson, P. (2012). "i didn't spel that wrong did i. Oops": Analysis and normalisation of SMS spelling. Lingvisticae Investigationes, 35(2), 367-388.

Thurlow, C., \& Brown, A. (2003). Generation Txt? The sociolinguistics of young people's text-messaging Discourse Analysis Online Retrieved June 18, 2013 from http://faculty.washington.edu/thurlow/papers/Thurlow\%282003\%29-DAOL.pdf.

Thurlow, C., \& Poff, M. (2013). Text Messaging. In S. C. Herring, S. Dieter \& V. Tuija (Eds.), Handbook of the Pragmatics of CMC (pp. 163-189). Berlin \& New York: Mouton de Gruyter.

UNESCO. (2010). mLearning : a plateform for educational opportunities at the base of the $\begin{array}{lllll}\text { pyramid } & \text { Retrieved June 18, } & 2013 \text { from }\end{array}$ http://www.gsma.com/mobilefordevelopment/wpcontent/uploads/2012/04/mlearningaplatformforeducationalopportunitiesatthebaseofth epyramid.pdf

Verschueren, J. (1999). Understanding pragmatics. London: Arnold.

Volckaert-Legrier, O., Bernicot, J., \& Bert-Erboul, A. (2009). Electronic mail, a new writtenlanguage register : A study with French-speaking adolescents. British Journal of Developmental Psychology, 27, 163-181. doi: 10.1348/026151008X368884

Wilkinson, G.S., \& Robertson, G.J. (2006). Wide Range Achievements Tests - 4 (WRAT-4). Psychological Assessment Ressources. FL: Lutz.

Wood, C., Jackson, E., Hart, L., Plester, B., \& Wilde, L. (2011a). The effect of text messaging on 9- and 10-year-old children's reading, spelling and phonological processing skills. Journal of Computer Assisted Learning, 27, 28-36. doi: 10.1111/j.13652729.2010.00398.x

Wood, C., Jackson, E., Plester, B., \& Wilde, L. (2009). Children's use of mobile phone text messaging and its impact on literacy development in primary school. British Educational Communications and Technology Agency (BECTA). 
Wood, C., Meachem, S., Bowyer, S., Jackson, E., Tarczynski-Bowles, M.L., \& Plester, B. (2011b). A longitudinal study of children's text messaging and literacy development. British Journal of Psychology, 102(3), 431-442. doi: 10.1111/j.20448295.2010.02002.x

Yenglin, I., Karahoca, A., Karahoca, D., \& Uzunboylu, H. . (2011). Is SMS still alive for education: Analysis of educational potentials of SMS technology? Procedia Computer Science, 3, 1439-1445. doi: 10.1016/j.procs.2011.01.027 

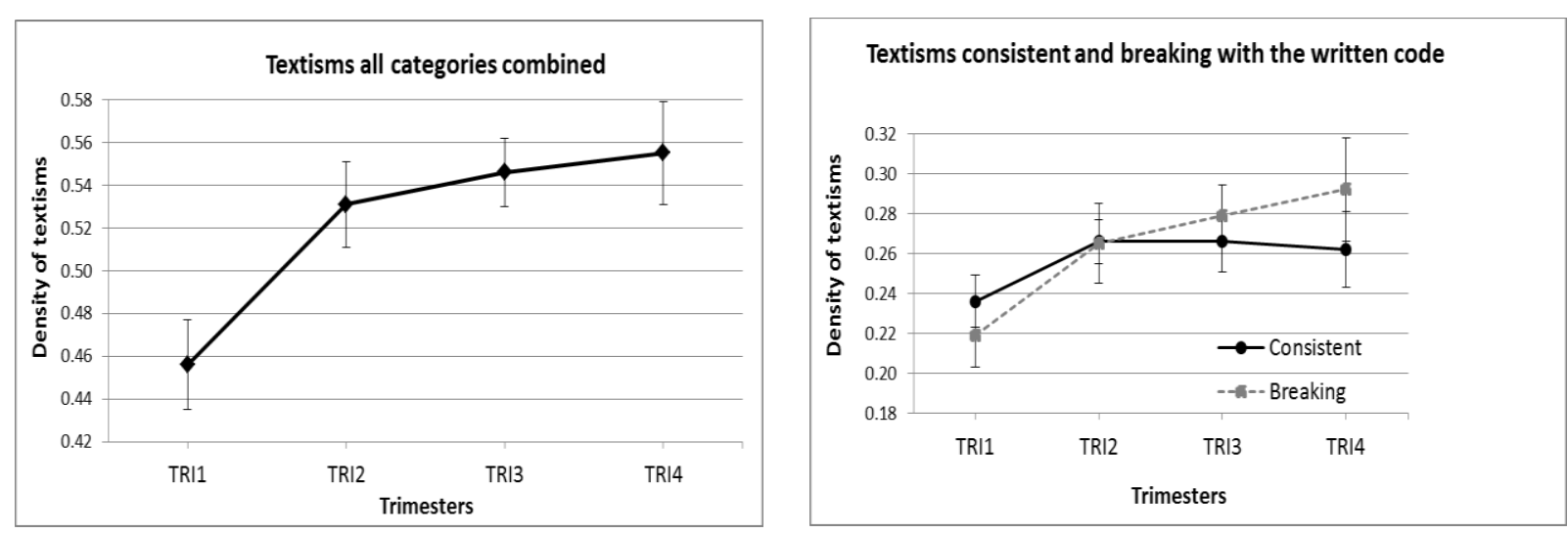

Figure 1 - Evolution of the density of textisms over one year: by trimesters (TRI) of practice. The vertical bars indicate the standard errors. 
Table 1 - Proportions of words with textisms for each textism category

Proportion of words without textisms $=.48$

Proportion of words with textisms $=.52$

Textisms consistent with the traditional code of phoneme-grapheme correspondence

$\begin{array}{lllll}\text { Categories } & \text { Simplifications } & \text { Complexifications } & \text { Substitutions } & \text { Total }\end{array}$

$\begin{array}{lllll}\text { Proportions } & .23 & .01 & .02 & .26\end{array}$

Textisms breaking with the traditional code of phoneme-grapheme correspondance

\begin{tabular}{|c|c|c|c|c|c|}
\hline Categories & $\begin{array}{l}\text { New phoneme- } \\
\text { grapheme } \\
\text { correspondences } \\
\text { without } \\
\text { phonological } \\
\text { modification } \\
05\end{array}$ & $\begin{array}{c}\text { Agglutinations } \\
05\end{array}$ & $\begin{array}{l}\text { Phonological } \\
\text { modifications } \\
13\end{array}$ & $\begin{array}{l}\text { Words or } \\
\text { graphic } \\
\text { forms non- } \\
\text { existent in } \\
\text { traditional } \\
\text { French } \\
\quad 03\end{array}$ & $\begin{array}{c}\text { Total } \\
26\end{array}$ \\
\hline
\end{tabular}


Table 2 - Comparison of traditional writing performance of the group with mobile phones and the group without mobile phones.

Table 2a - Average school grades in French for trimesters 1, 2, and 3.

\begin{tabular}{llll}
\hline & Trimester 1 & Trimester 2 & Trimester 3 \\
\hline Group with & 13.66 & 12.66 & 12.55 \\
\hline Group without & 14.23 & 12.94 & 12.52 \\
\hline
\end{tabular}

Table $2 b$ - Average scores on the ANALEC standardized spelling test (Inizan, 1998)

\begin{tabular}{|c|c|c|c|c|}
\hline & $\begin{array}{l}\text { Usage-based } \\
\text { spelling }\end{array}$ & $\begin{array}{l}\text { Rule-based } \\
\text { spelling }\end{array}$ & Silent dictation & Total score \\
\hline & Maximum: 28 & Maximum: 16 & Maximum: 18 & Maximum: 62 \\
\hline Group with & 24.32 & 11.11 & 13.05 & 48.47 \\
\hline Group without & 24.77 & 10.93 & 13.33 & 49.03 \\
\hline
\end{tabular}


Table 3 - Correlations between the grades in French class (Bravais Pearson's $r$ ) for each of the 4 trimesters for the group with mobile phones, and each of the 3 trimesters for the group without mobile phones.

Table 3a - Group with mobile phones

\begin{tabular}{lllll}
\hline & $\begin{array}{l}\text { French } \\
\text { Trimester } 1\end{array}$ & $\begin{array}{l}\text { French } \\
\text { Trimester 2 }\end{array}$ & $\begin{array}{l}\text { French } \\
\text { Trimester 3 }\end{array}$ & $\begin{array}{l}\text { French } \\
\text { Trimester 4 }\end{array}$ \\
\hline $\begin{array}{l}\text { French } \\
\text { Trimester } 1\end{array}$ & & $.71 * * *$ & $.73 * * * *$ & $.61 * *$ \\
\hline $\begin{array}{l}\text { French } \\
\text { Trimester } 2\end{array}$ & $.71 * * *$ & $.68 * * *$ & $.59 *$ \\
\hline $\begin{array}{l}\text { French } \\
\text { Trimester } 3\end{array}$ & $.73 * * * *$ & $.68 * * *$ & $.72 * * *$ \\
\hline $\begin{array}{l}\text { French } \\
\text { Trimester } 4\end{array}$ & $.61 * *$ & $.59 *$ & $.72 * * *$ & \\
\hline$* p<.01-* * p<.005-* * * p<.001-* * * * p<.0001$ & & \\
\hline
\end{tabular}

Table $3 b$ - Group without mobile phones

\begin{tabular}{llll}
\hline & $\begin{array}{l}\text { French } \\
\text { Trimester 1 }\end{array}$ & $\begin{array}{l}\text { French } \\
\text { Trimester 2 }\end{array}$ & $\begin{array}{l}\text { French } \\
\text { Trimester 3 }\end{array}$ \\
\hline $\begin{array}{l}\text { French } \\
\text { Trimester 1 }\end{array}$ & & $.75^{* * * *}$ & $.81 * * * *$ \\
\hline $\begin{array}{l}\text { French } \\
\text { Trimester } 2\end{array}$ & $.75 * * * *$ & & $.79 * * * *$ \\
\hline $\begin{array}{l}\text { French } \\
\text { Trimester 3 }\end{array}$ & $.81 * * * *$ & $.79 * * * *$ & \\
$* * * * p<.0001$ & & &
\end{tabular}


Table 4 - Correlations (Bravais Pearson's $r$ ) between the ANALEC spelling test scores (Inizan, 1998) and the grades in French class for each of the 4 trimesters for the group with mobile phones, and each of the 3 trimesters for the group without mobile phones.

Table 4a - Group with mobile phones

\begin{tabular}{lllll}
\hline & $\begin{array}{l}\text { French } \\
\text { Trimester 1 }\end{array}$ & $\begin{array}{l}\text { French } \\
\text { Trimester 2 }\end{array}$ & $\begin{array}{l}\text { French } \\
\text { Trimester 3 }\end{array}$ & $\begin{array}{l}\text { French } \\
\text { Trimester 4 }\end{array}$ \\
\hline $\begin{array}{l}\text { Usage-based } \\
\text { spelling }\end{array}$ & $.55^{* *}$ & .25 & .37 & $.49^{*}$ \\
\hline $\begin{array}{l}\text { Rule-based } \\
\text { spelling }\end{array}$ & $.59^{* *}$ & $.64^{* *}$ & $.61^{* *}$ & .34 \\
\hline $\begin{array}{l}\text { Silent } \\
\text { dictation }\end{array}$ & .44 & .23 & .30 & $.49^{*}$ \\
\hline Total score & $.71^{* * *}$ & $.46^{*}$ & $.55^{* *}$ & $.61^{* *}$ \\
\hline
\end{tabular}

$* p<.05-* * p<.01-* * * p<.001$

Table $4 \mathrm{~b}$ - Group without mobile phones

\begin{tabular}{llll}
\hline & $\begin{array}{l}\text { French } \\
\text { Trimester } 1\end{array}$ & $\begin{array}{l}\text { French } \\
\text { Trimester 2 }\end{array}$ & $\begin{array}{l}\text { French } \\
\text { Trimester 3 }\end{array}$ \\
\hline $\begin{array}{l}\text { Usage-based } \\
\text { spelling }\end{array}$ & $.39 *$ & $.40^{*}$ & $.57 * * * *$ \\
\hline $\begin{array}{l}\text { Rule-based } \\
\text { spelling }\end{array}$ & $.56 * * * *$ & $.50 * * *$ & $.68 * * * * *$ \\
\hline $\begin{array}{l}\text { Silent } \\
\text { dictation }\end{array}$ & $.39 *$ & .32 & $.57 * * * *$ \\
\hline Total score & $.51 * * *$ & $.46^{* *}$ & $.69 * * * * *$ \\
\hline
\end{tabular}

$* p<.05-* * p<.01-* * *<.005-* * * * p<.001-* * * * * p<.0001$ 
Table 5 - Correlation (Bravais Pearson's $r$ ) between the density of textisms and the ANALEC spelling test scores (Inizan, 1998)

Textisms (all categories combined)

\begin{tabular}{lllll}
\hline & $\begin{array}{l}\text { Textisms } \\
\text { Trimester } 1\end{array}$ & $\begin{array}{l}\text { Textisms } \\
\text { Trimester } 2\end{array}$ & $\begin{array}{l}\text { Textisms } \\
\text { Trimester } 3\end{array}$ & $\begin{array}{l}\text { Textisms } \\
\text { Trimester } 4\end{array}$ \\
\hline $\begin{array}{l}\text { Usage-based } \\
\text { spelling }\end{array}$ & $.55^{* *}$ & $.56^{* *}$ & .43 & -.23 \\
\hline $\begin{array}{l}\text { Rule-based } \\
\text { spelling }\end{array}$ & .06 & .01 & -.16 & $-.71^{* * *}$ \\
\hline $\begin{array}{l}\text { Silent } \\
\text { dictation }\end{array}$ & .23 & .05 & .29 & .03 \\
\hline Total score & .41 & .31 & .30 & -.35 \\
\hline
\end{tabular}

Textisms consistent with the code

\begin{tabular}{lllll}
\hline & $\begin{array}{l}\text { Textisms } \\
\text { Trimester 1 }\end{array}$ & $\begin{array}{l}\text { Textisms } \\
\text { Trimester 2 }\end{array}$ & $\begin{array}{l}\text { Textisms } \\
\text { Trimester 3 }\end{array}$ & $\begin{array}{l}\text { Textisms } \\
\text { Trimester 4 }\end{array}$ \\
\hline $\begin{array}{l}\text { Usage-based } \\
\text { spelling }\end{array}$ & .04 & -.06 & .14 & -.14 \\
\hline $\begin{array}{l}\text { Rule-based } \\
\text { spelling }\end{array}$ & -.24 & -.12 & -.09 & -.28 \\
\hline $\begin{array}{l}\text { Silent } \\
\text { dictation }\end{array}$ & .29 & .10 & .21 & .02 \\
\hline Total score & .08 & -.02 & .14 & -.16 \\
\hline
\end{tabular}

Textisms breaking with the code

\begin{tabular}{lllll}
\hline & $\begin{array}{l}\text { Textisms } \\
\text { Trimester } 1\end{array}$ & $\begin{array}{l}\text { Textisms } \\
\text { Trimester } 2\end{array}$ & $\begin{array}{l}\text { Textisms } \\
\text { Trimester 3 }\end{array}$ & $\begin{array}{l}\text { Textisms } \\
\text { Trimester 4 }\end{array}$ \\
\hline $\begin{array}{l}\text { Usage-based } \\
\text { spelling }\end{array}$ & $.69^{* * *}$ & $.60^{* *}$ & .32 & -.11 \\
\hline $\begin{array}{l}\text { Rule-based } \\
\text { spelling }\end{array}$ & .27 & .08 & -.08 & $-.46^{*}$ \\
\hline $\begin{array}{l}\text { Silent } \\
\text { dictation }\end{array}$ & .07 & -.01 & .10 & .01 \\
\hline Total score & $.47 *$ & .32 & .18 & -.21 \\
\hline
\end{tabular}

$* p<.05-* * p<.01-* * * p<.001$ 

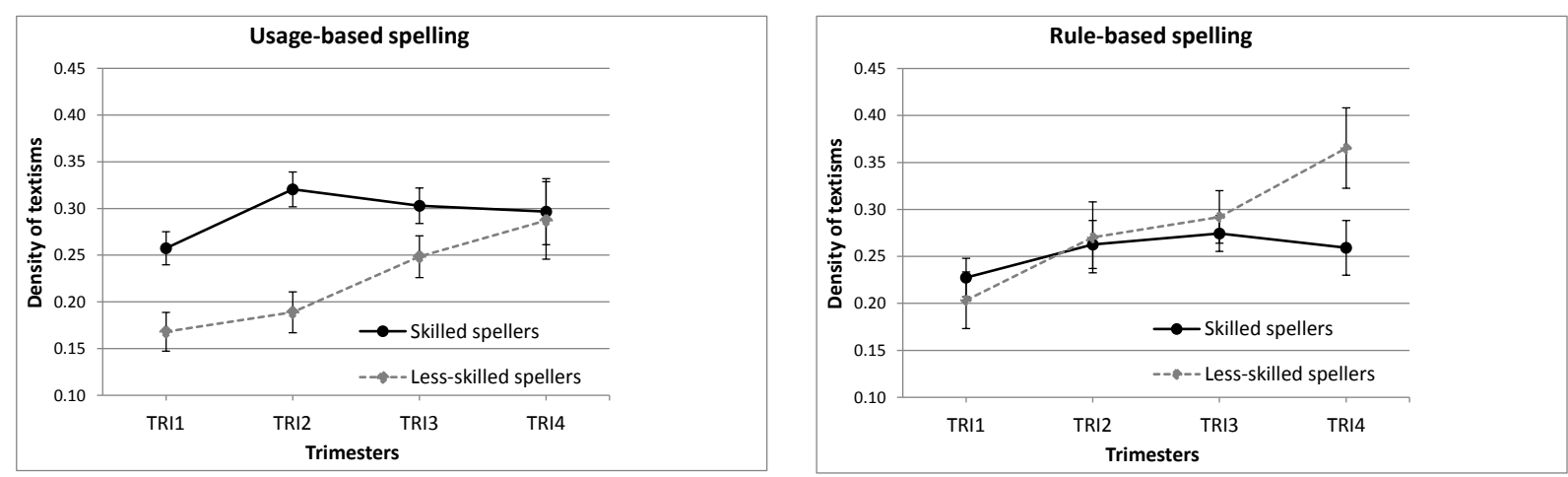

Figure 2 - Evolution of the density of textisms breaking with the code by trimesters (TRI) of practice and by the participants' spelling level. The vertical bars indicate the standard errors. 
